\title{
An overview of groundwater in Scotland
}

\author{
Alan M MacDonald ${ }^{1}$, Nick S Robins ${ }^{2}$, Derek F Ball ${ }^{1} \&$ Brighid É Ó Dochartaigh ${ }^{1}$ \\ 1 British Geological Survey, Murchison House, West Mains Road, Edinburgh, EH4 3LA, \\ amm@bgs.ac.uk \\ ${ }^{2}$ British Geological Survey, MacLean Building, Crowmarsh Gifford, Wallingford, OXON, OX10 8BB.
}

\section{Synopsis}

Groundwater is an important, but undervalued, national resource in Scotland. Groundwater is present both in the bedrock, where much of the flow is through fractures, and in the superficial deposits, where intergranular flow dominates. The most productive bedrock aquifers are the Permian sandstones and breccia in southwest Scotland and the Devonian sandstones in Fife, Strathmore and Morayshire. Alluvium and fluvio-glacial sands and gravels can also form important aquifers and provide some of Scotland's most highly yielding boreholes. Groundwater is generally weakly mineralised with total dissolved solids in the range 100 to $500 \mathrm{mg} \mathrm{l}^{-1}$ and is dominated by $\mathrm{Ca}$ and $\mathrm{HCO}_{3}$ type waters.

There are in excess of 4000 boreholes in Scotland, and over 20000 springs and wells used for private water supply. There is little available reliable data on the total volumes of groundwater abstracted; however, conservative estimates suggest that the total volume is approximately 330 megalitres per day for public water supply, industry, agriculture and private water supply. The volume of groundwater used in public water supply is growing annually; currently 7\% of the daily 2400 megalitres per day supplied by Scottish Water. Scottish groundwater is under threat from agricultural activity, the mining legacy, septic tanks and general land development. The implementation of the EU Nitrates and Water framework directives is an excellent opportunity to sustainably manage and develop groundwater in Scotland.

Running title: An overview of groundwater in Scotland 


\section{Introduction}

Groundwater is an important resource for Scotland. Water from boreholes and springs contributes to public, industrial and agricultural water supply as well as supporting many rural properties. Groundwater forms the basis of the growing mineral water industry in Scotland and is also used to produce, and market, whisky. However, despite the obvious importance of groundwater it is often undervalued and overlooked as a national asset - probably because of our notorious high rainfall.

Many farmhouses and rural dwellings built before the twentieth century possessed a well beneath the kitchen floor or in the yard outside. The arrival of the steam drilling machine in the late Victorian era provided industry with access to groundwater, but it was interest in dewatering the particularly wet coal mines of central Scotland that first brought groundwater investigation to the fore (Robins et al. 2004).

Early interest in groundwater was championed by the Edinburgh Office of the Geological Survey of Great Britain. Some of Scotland’s most famous geologists, Ben Peach and John Horne, and later T R Robertson and A G (Archie) MacGregor wrote many of the groundwater reports in the early years. The first overview of groundwater occurrence in the Midland Valley was that by Cumming (1936), but it took until 1977 before a dedicated hydrogeologist was appointed to the Survey Office in Edinburgh (Ian Harrison) following the earlier appointment of a hydrogeologist (Tricia Henton) to the Clyde River Purification Board.

Springs have formed an important part of public water supply since the $19^{\text {th }}$ century most notably supplying the city of Edinburgh. Borehole drilling for public supply commenced in earnest in the 1970s in Dumfries and Fife when it was realised that cost effective potable supplies requiring little treatment could be obtained from groundwater 
in some areas. Development continued throughout the 1980s; this development phase of hydrogeological investigation was capped with two milestones, the publication of the Hydrogeological Map of Scotland (British Geological Survey 1988) and an accompanying description (Robins 1990).

The next phase of groundwater science concentrated on resource protection as well as development. This was heralded by the publication of a national groundwater protection strategy (ADRIS 1995) and development of groundwater vulnerability maps for selected areas, e.g. the national vulnerability map published with ADRIS (1995). A great deal of effort was also put into evaluating contaminated land and other point sources of pollution, both with regard to environmental protection and to land development.

The current phase of hydrogeological investigation in Scotland is one of resource and source management. The drivers are the incoming Directives from the European Union, including the Nitrate Directive and the Water Framework Directive, each of which requires considerable hydrogeological input (see Clews et al. this volume). Central to groundwater management is the role of the national environmental regulator, the Scottish Environment Protection Agency. Recent advances in computing power and in particular the availability of Geographic Information System formats are now enabling existing large data sets to be reanalysed on a national scale. A number of major analytical projects have recently provided considerable advances in the understanding of the hydrogeology of Scotland, including the designation of areas at risk from nitrate and pesticide pollution (Ball et al. this volume), groundwater that is vulnerable to pollution (Ó Dochartaigh et al. this volume), and aquifer productivity (MacDonald et al. 2004). 
This paper describes an overview of our current understanding of groundwater in Scotland. An extensive reference list is given to help follow up some of the issues in more detail.

\section{Groundwater occurrence}

Groundwater occurs throughout Scotland in many different environments and rock types. However, the resource accessible from different rock types varies markedly depending on the permeability and porosity. In bedrock aquifers, much of the flow is through fractures - intergranular flow is important in only a few sandstone formations (see Table 1). In superficial deposits intergranular flow dominates and fracture flow only occurs in low permeability tills, which have negligible groundwater potential. Recently, GIS-based maps (designed to be used at a scale of 1:100 000) of the accessible groundwater resources across Scotland have been produced for both bedrock and superficial deposits (MacDonald et al. 2004).

\section{Bedrock aquifers}

Table 1 gives a summary of the flow types and aquifer productivity for bedrock in Scotland; the distribution is shown in Figure 1. The term "aquifer productivity" has been used to describe the potential of an aquifer (bedrock or superficial deposit) to sustain various levels of borehole supply. Properly sited boreholes (or for superficial deposits, a group of boreholes) in high and very high productivity aquifers have the potential to be considered a source for public supply or for industry. Low productivity formations are considered suitable for groundwater supplies to single or small groups of houses. 
The flow characteristics and classifications have been made with reference to various sources: laboratory hydraulic data; geophysical logs; and pumping test data where available. However for much of Scotland these data are not available and the classifications are based solely on lithological descriptions of the rocks, borehole records, drilling experience and the BGS hydrogeological map of Scotland (BGS 1988). The most productive bedrock aquifers in Scotland are the Permian sandstones and breccias in southwest Scotland, and the Devonian sandstones in Fife and eastern Scotland.

Permian aquifers of South West Scotland The Permian aquifers of southwest Scotland comprise thick sequences of aeolian sandstones and breccias. Hydrogeological and geophysical investigations have demonstrated that the breccias and sandstones have different hydrogeological properties (Robins \& Buckley 1988; Robins 1990; Buckley 2000; MacDonald et al. 2003).

Detailed geophysical logging in various boreholes penetrating breccia has shown that much of the inflow is from only $3-5$ fractures, the most productive fractures are between breccia and sandstone layers. Individual fractures have been measured contributing more than $45 \%$ of the flow (Buckley 2000). Further evidence of rapid groundwater flow over several kilometres and limited groundwater storage in the breccias has been given by a combined study of groundwater quality and age (MacDonald et al. 2003). Pumping tests within the breccia indicate transmissivity from $9-4000 \mathrm{~m}^{2} \cdot \mathrm{d}^{-1}$ with a geometric mean of $400 \mathrm{~m}^{2} \cdot \mathrm{d}^{-1}$ (from 11 tests). Laboratory measurements from core samples from the breccia indicate an average porosity of $8 \%$ 
(mean of samples from 2 boreholes) and hydraulic conductivity of less than $10^{-4}$ m.day ${ }^{-1}$ (Robins \& Buckley 1988; Cheney \& MacDonald 1993).

The transmissivity of the sandstones is lower, but the storage higher. Average porosity is $20-30 \%$ and hydraulic conductivity is generally less than $1 \mathrm{~m} \cdot \mathrm{d}^{-1}$ (Robins \& Buckley 1988; Cheney \& MacDonald 1993). In Arran, where the sandstones have been baked by igneous intrusions, intergranular porosity and permeability is much less. There are fewer pumping test from the sandstones, but average transmissivity from four tests is $200 \mathrm{~m}^{2} \cdot \mathrm{d}^{-1}$. Geophysical logging (Robins \& Buckley 1988; Buckley 2000) again indicates that much of the inflow to boreholes is through fractures, but overall regional flow is slow and likely to be intergranular (MacDonald et al. 2003).

Devonian Aquifer of Fife Three formations, the Knox Pulpit formation, Kinnesswood formation and Glenvale formation form the Fife Devonian aquifer. These and other Devonian formations are not as productive where they occur elsewhere. There is considerable variation in porosity and hydraulic conductivity with depth in the aquifer, reflecting variations in grain size. Geophysical logging of boreholes has shown that even where porosity is highest (greater than 20\%), fracture flow is still dominant, constituting at least $70 \%$ of inflow to boreholes. Highest permeability occurs in the uppermost 10 to $15 \mathrm{~m}$ of the saturated zone, where weathering and fracture development have significantly increased secondary permeability (Ó Dochartaigh et al. 1999). Mean porosity for the four formations is $19.4 \%$ (from 10 boreholes) and hydraulic conductivity $0.06 \mathrm{~m} \cdot \mathrm{d}^{-1}$. Pumping tests from 5 boreholes indicate transmissivity from $200-800 \mathrm{~m}^{2} \cdot \mathrm{d}^{-1}$ with a geometric mean of $350 \mathrm{~m}^{2} \cdot \mathrm{d}^{-1}$. 


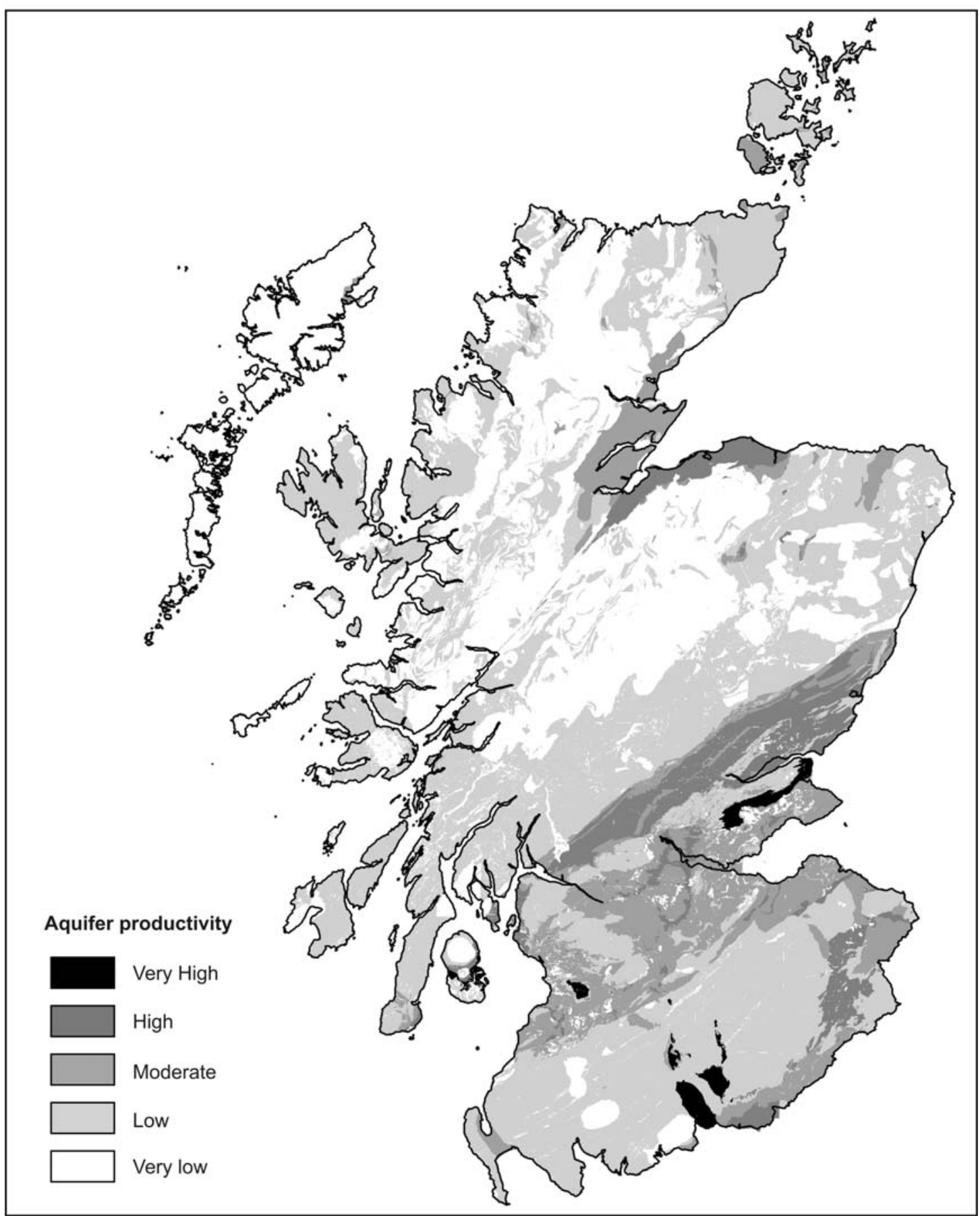

Figure 1 Bedrock aquifer productivity across Scotland. 
Table 1 A summary of bedrock aquifer productivity in Scotland.

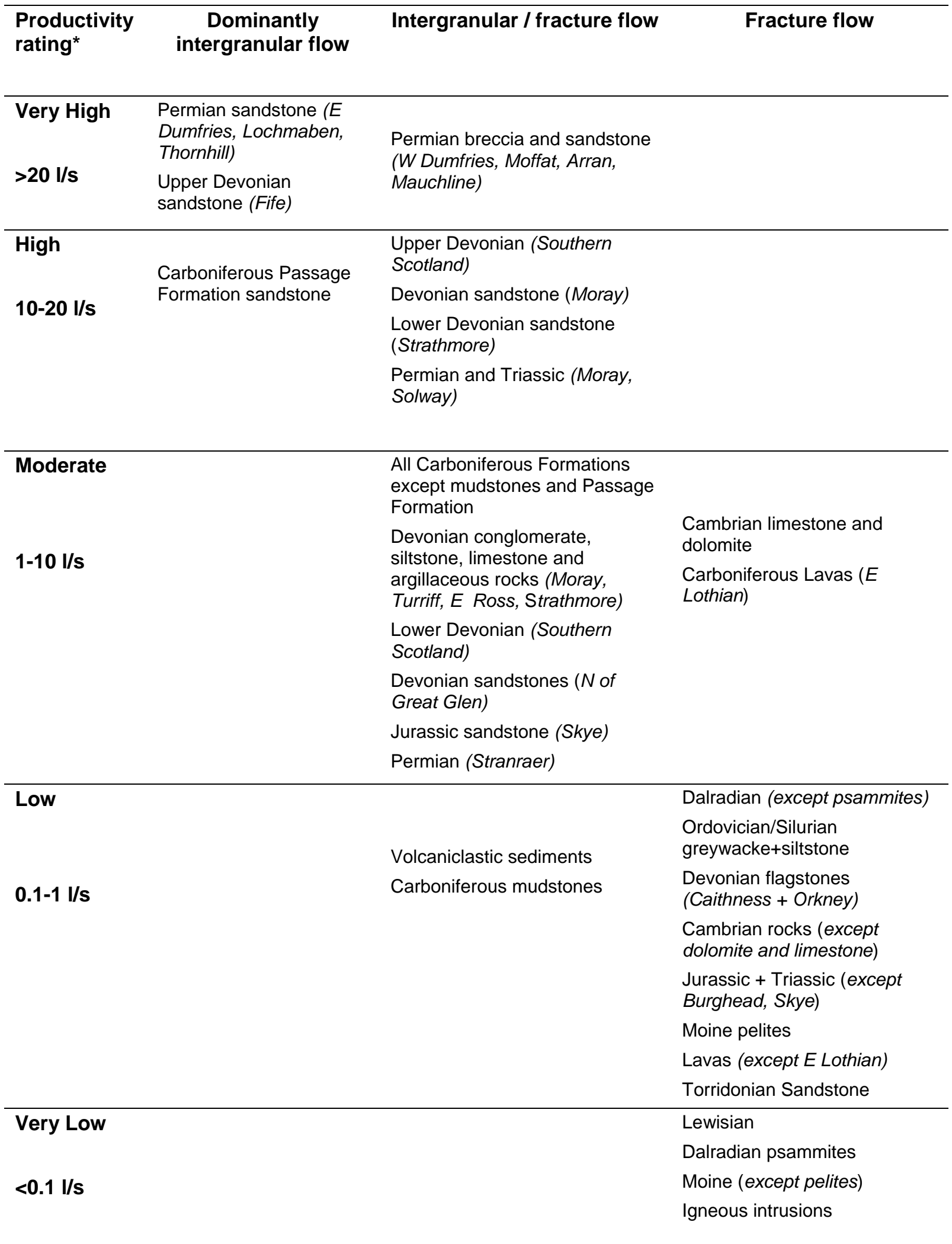

* The productivity rating refers to the estimated typical long-term yield from a single, properly sited and constructed borehole. 


\section{Superficial Aquifers}

Table 2 gives a summary of aquifer productivity for superficial deposits in Scotland; the distribution is shown in Figure 2. All superficial deposits are assumed to have primarily intergranular groundwater flow (although fracture flow may be important in some tills). The superficial aquifer map is subdivided into three classes according to productivity (high, moderate and low), with the remainder classed as non-aquifer. The classifications were made using BGS data, geological descriptions and the Hydrology of Soil Types (HOST) classifications of the Macaulay Institute (Boorman et al. 1995; Lilly et al. 1998). The productivity is potential, because many of the deposits may be too thin to actually contain groundwater. Ó Dochartaigh et al. (this volume) explain the methodology used to determine areas of partially saturated or dry superficial deposits.

High productivity superficial aquifers comprise deposits that have significant sand and gravel content, such as glaciofluvial sand and gravel and alluvium. All mapped alluvium and glaciofluvial deposits are included in this category - there are insufficient data to account for variations in permeability and thickness within alluvium and glaciofluvial deposits. Alluvial deposits within valley floodplains, although possibly less than $10 \mathrm{~m}$ in thickness, may have the capability to support very large abstraction rates wherever there is good hydraulic contact with adjacent watercourses. Some of the highest yielding boreholes in Scotland are from alluvium deposits. Several large public water supply abstractions are located in high productivity superficial aquifers (Jones \& Singleton 2000).

Moderate productivity aquifers comprise mainly raised marine deposits. Typically, these contain a high proportion of silt and clay and, therefore, have lower permeability 
than the well-sorted, coarser, high productivity deposits. They are also generally thin, which reduces their potential for yielding large volumes of groundwater even further. Blown sand is also included in this category since, despite its high permeability, it is rarely more than a few metres thick and is distant from main rivers. Small public water supply abstractions have been located within moderate permeability aquifers in parts of rural Scotland. However geophysical techniques are often required to help find the best locations for boreholes (MacDonald et al. 2000).

Low productivity aquifers comprise sandy and gravelly tills, moraines, mixed lacustrine deposits and landslip material. Much of Scotland is covered by till but only high permeability till and moraine are considered as aquifers. Although variations in till lithology are recognised across Scotland by BGS geologists there is little relevant information on till lithological variation in the available maps. In order to provide support to geologists' descriptions, till has been subdivided according to permeability using the Hydrology of Soil Types (HOST) dataset of soil hydraulic properties developed jointly by the Soil Survey and Land Research Centre, the Macaulay Institute and the Centre for Ecology and Hydrology (Boorman et al. 1995; Lilly et al. 1998). The methodology for subdividing the tills is described in detail in Ball et al. (2003). In general the more permeable tills are found across much of the Highlands, Aberdeenshire and southern Scotland.

Non aquifers have by definition no aquifer productivity and have been omitted from the map. These include the moderate and low permeability tills of Strathmore and Central Scotland, and estuarine, marine or lacustrine clays. 
Table 2 A summary of superficial aquifer productivity in Scotland.

\begin{tabular}{ll} 
Productivity rating & Superficial deposits \\
\hline High & IH \\
Glo I/s & $\begin{array}{l}\text { Glaciofluvial sand and gravel \& mixed deposits } \\
\text { Alluvium + River Terrace sand \& gravel (majority of Scotland) }\end{array}$ \\
Moderate & IM \\
1-10 I/s & $\begin{array}{l}\text { Raised Marine deltaic deposits (mixed) } \\
\text { Raised Beach and Marine deposits } \\
\text { Blown sand }\end{array}$ \\
Low & $\begin{array}{l}\text { IL } \\
\text { Sandy and gravelly glacial till } \\
\text { 0.1-1 I/s }\end{array}$ \\
& $\begin{array}{l}\text { Hummocky moraine } \\
\text { Mixed lacustrine deposits } \\
\text { Landslip }\end{array}$ \\
\hline
\end{tabular}




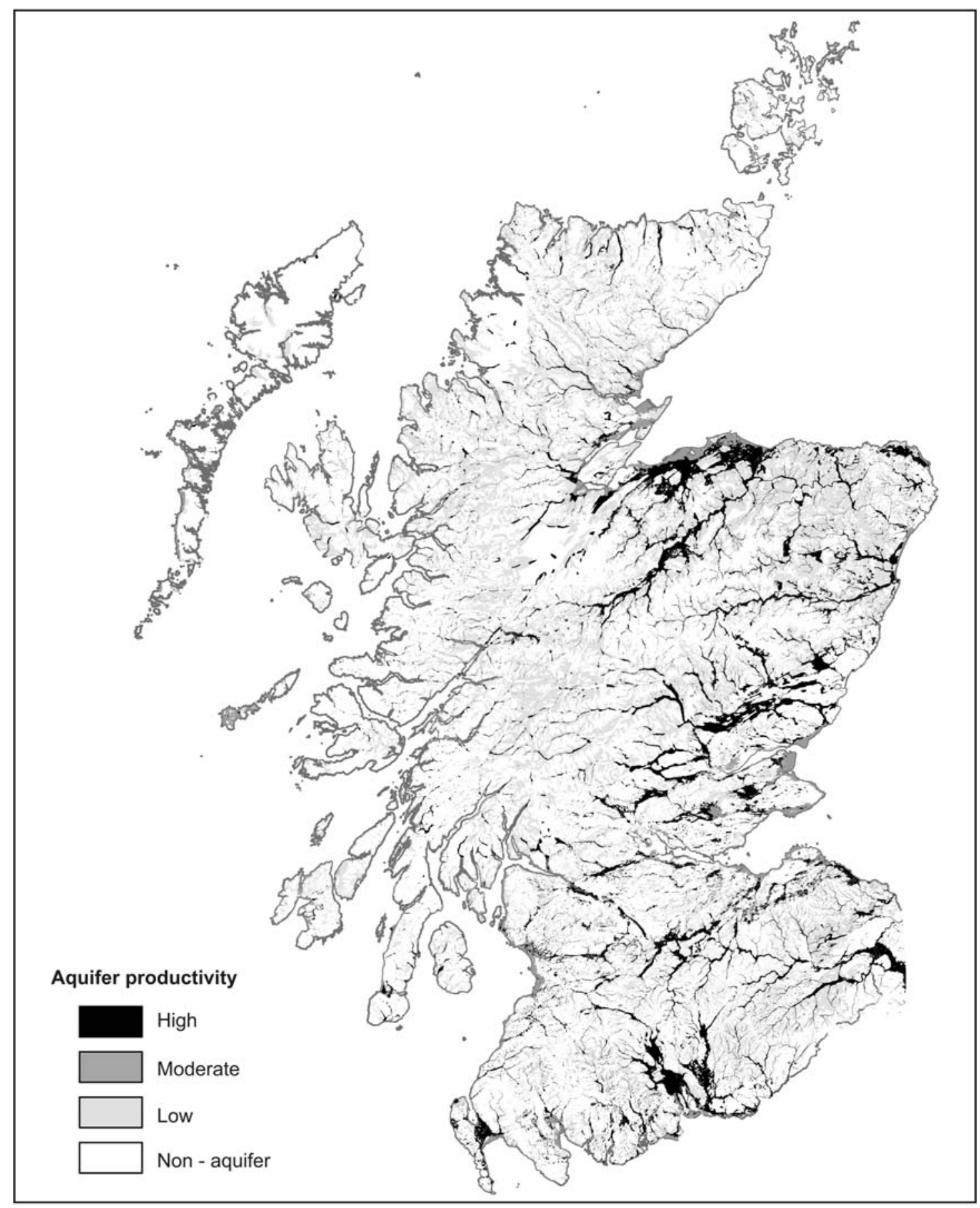

Figure 2 Superficial aquifer productivity across Scotland. 


\section{Hydrochemistry}

Much of the groundwater in Scotland is weakly mineralised with total dissolved solids in the range 100 to $500 \mathrm{mg} \mathrm{l}^{-1}$ and is dominated by $\mathrm{Ca}$ and $\mathrm{HCO}_{3}$. Figure 3 shows the near linear correlation between $\mathrm{Ca}$ and $\mathrm{HCO}_{3}$ for the majority of Scottish groundwaters in bedrock, a relationship which only fails when Ca exceeds $100 \mathrm{mg} \mathrm{l}^{-1}$, but is otherwise largely valid. Most Scottish groundwaters remain oxidised, and there are few occurrences of reducing conditions. This reflects the relatively small size of many of the groundwater units and the short flow paths within them. Below is a summary of the main characteristics of groundwater quality in Scotland from the available data (Robins 2002)

- Groundwater in the basement rocks of the Southern Uplands offers a diverse range of water quality ranging from acidic to alkaline and from weakly to strongly mineralised. Groundwater in the Precambrian crystalline rocks of the Highlands is, for the most part, weakly mineralises with $\mathrm{HCO}_{3}$ concentrations less than $300 \mathrm{mg} \mathrm{l}^{-1}$.

- Devonian aquifers in the Midland Valley and Strathmore generally contain alkaline water dominated by the $\mathrm{Ca}-\mathrm{HCO}_{3}$ combination of ions, although $\mathrm{Cl}$ and $\mathrm{SO}_{4}$ are important also in some areas.

- Carboniferous rocks offer similarly alkaline groundwaters except where mining has reduced the $\mathrm{pH}$ creating reducing waters with $\mathrm{Fe}$ and $\mathrm{Al}$ in solution. In addition to the usual $\mathrm{Ca}-\mathrm{HCO}_{3}$ groundwater type, some Carboniferous groundwaters veer towards $\mathrm{Na}-\mathrm{SO}_{4}$ and $\mathrm{Na}-\mathrm{Cl}$ dominance. 
- The Permo-Triassic and Jurassic aquifers which have a silicic matrix tend to contain water of neutral $\mathrm{pH}$ of the $\mathrm{Ca}-\mathrm{HCO}_{3}$ and $\mathrm{Ca}(\mathrm{Mg})-\mathrm{HCO}_{3}$ types. Occurrence of dolomitic cement in sandstones in Morayshire creates $\mathrm{Mg}-\mathrm{HCO}_{3}$ type groundwaters, whereas gypsum in the Lochmaben basin creates $\mathrm{Ca}^{-\mathrm{SO}_{4}}$ type groundwaters.

- Groundwater quality in superficial rock strata is of variable chemical type depending on the prevailing mineralogy and connectivity with bedrock groundwaters and surface waters. Groundwater is typically of near neutral $\mathrm{pH}$ with $\mathrm{HCO}_{3}$ concentrations less than $100 \mathrm{mg} \mathrm{l}^{-1}$. High iron and manganese concentrations are often found within the superficial deposits where localised conditions are reducing.

- There are some deeper circulating and more mature groundwaters which mostly discharge at former Spa sites (Robins \& Ferry 1992). These include Bridge of Earn, south of Perth, which has a Cl concentration of $1250 \mathrm{mg} \mathrm{l}^{-1}$, and the Na dominated waters of Moffat, Innerleithen and Melrose in the Southern Uplands. Strathpeffer Spa, north of Inverness, is a young groundwater which has $\mathrm{SO}_{4}$ concentrations up to $925 \mathrm{mg} \mathrm{l}^{-1}$ derived from contact with the shallow fetid and bituminous Spa Beds.

The presence of nitrate in groundwater is a concern across much of Scotland (see Ball et al. this volume). Concentrations in excess of $25 \mathrm{mg}-\mathrm{NO}_{3} \mathrm{l}^{-1}$ are common throughout eastern Scotland where excess nitrogen is produced from farming and the aquifers are vulnerable. In the Eden Valley in Fife some boreholes in Devonian sandstone show a rising trend of up to $8 \mathrm{mg}-\mathrm{NO}_{3} \mathrm{l}^{-1}$ decade ${ }^{-1}$ since the late 1970s. In the Dumfries Aquifer Basin one public supply borehole has reacted to local over-pumping with a 
recorded concentration of only $6 \mathrm{mg}-\mathrm{NO}_{3} \mathrm{l}^{-1}$ in 1978 to over $26 \mathrm{mg}-\mathrm{NO}_{3} \mathrm{l}^{-1}$ today (Robins 2002). MacDonald et al. (2003) further investigated rising nitrate concentrations in the Dumfries Aquifer Basin using $\mathrm{CFC}$ and $\mathrm{SF}_{6}$ as residence time indicators. The work demonstrated that concentrations of $\mathrm{NO}_{3}$ correlate directly to the age of the groundwater, with modern groundwater approaching 50 mg- $\mathrm{NO}_{3} \mathrm{l}^{-1}$ whereas pre-1950s groundwater contained $<10 \mathrm{mg}-\mathrm{NO}_{3} \mathrm{l}^{-1}$. Overall concentrations will continue to increase in the future as the pre-1950s water is progressively abstracted from the aquifer.

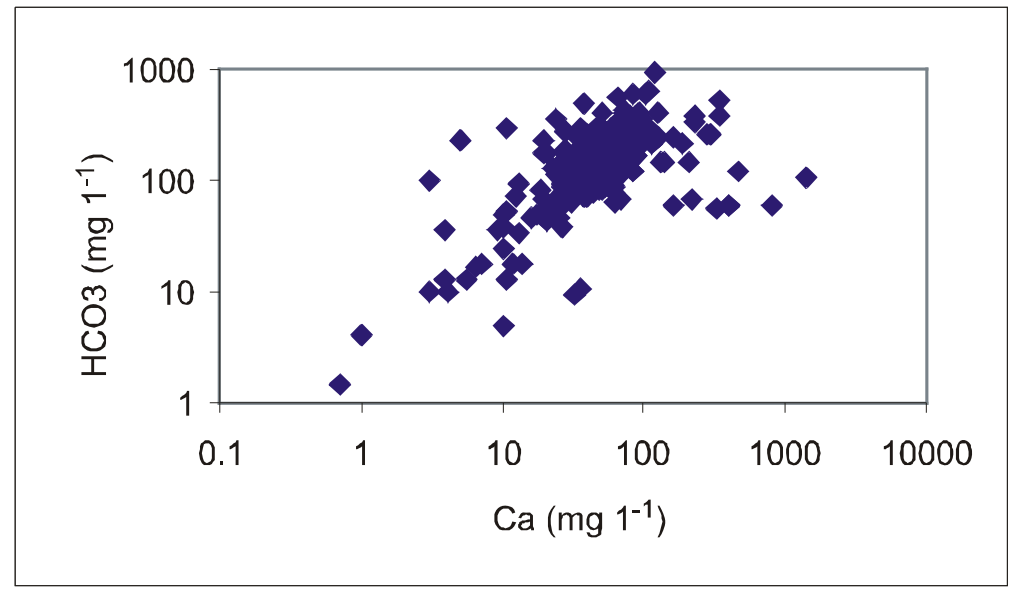

Figure 3 The relation between calcium and bicarbonate for Scottish groundwaters.

There have been a number of specific hydrochemical investigations that have been undertaken. The first centred on groundwater provenance and age in the Strath Halladale Granite (Kay 1984). Others concentrated on specific issues, Cook et al. (1991) considered the hydrochemistry of granite waters subject to low $\mathrm{pH}$ rainfall, Soulsby et al. (1998) considered the groundwater chemistry of an upland catchment and 
Wood et al. (1999) discussed the issues surrounding mine drainage in the Midland Valley.

\section{Groundwater use}

Groundwater is widely used in Scotland, despite the abundance of surface water. Table 3 gives the approximate volumes abstracted for different uses. Since no abstraction licensing yet exists in Scotland, these volumes are only approximate, based on information from the BGS groundwater databases, Scottish Water, and the private water supply database. A significant omission in this table is the environmental use of groundwater as baseflow to rivers and sustaining wetlands. There are in excess of 4000 boreholes across Scotland used for public and private supply, industry and agriculture, and many more (approximately 20 000) small springs and wells used for private water supply.

Table 3 Average daily groundwater use in Scotland 2004. There is considerable uncertainty around the amount used for agriculture and private water supplies

\begin{tabular}{ll}
\hline Use & Volume MI/d \\
\hline Public Water Supply boreholes & 100 \\
Public Water Supply springs $^{\mathrm{a}}$ & 70 \\
Industry $^{\text {Agriculture }}$ & 80 \\
Private Water Supplies $^{\mathrm{b}}$ & 40 \\
Total & 40 \\
\hline
\end{tabular}

${ }^{\mathrm{a}}$ The volume of water from springs may be much higher as springs that feed into a reservoir are often classified as surface water

${ }^{\mathrm{b}}$ There is considerable confusion surrounding the amount of groundwater used in private water supplies, this estimate is conservative. 


\section{Public water supply}

Groundwater, either abstracted from boreholes or captured from springs, comprises approximately 7\% of public water supply in Scotland. This relatively small proportion, however, hides the true strategic and economic importance of groundwater (see the location of the main borehole supplies in Figure 4). In small rural communities where less than $0.1 \mathrm{Ml} / \mathrm{d}$ is required, a borehole is an attractive alternative to piping water $10 \mathrm{~s}$ of kilometres or installing expensive treatment plants to treat peaty surface water (Grose et al. 1998). In 2004, there are 40 sites abstracting groundwater for public water supply. Scottish Water are increasingly exploring groundwater options for rural communities.

The main bedrock aquifers exploited for public water supply public are the Permian Basin of Dumfries (Robins \& Ball in press); the Devonian aquifer in Fife (Ó Dochartaigh et al 1999) and the Permian sediments in western Arran (Ball \& Buckley 1998). High yielding supplies from superficial deposits are found in Fort William (Johnstone \& Rennie 1991) the Spey Valley (Watt et al. 1987) and Howden, in the Borders (see Figure 4).

The true volume of groundwater used for public water supply is likely to be much higher than the 7\% quoted above. Many springs are captured and fed into reservoirs (e.g. the Pentland springs south of Edinburgh) before being used for public water supply: these sources are classed as surface water. In addition, baseflow from groundwater contributes up to $30 \%$ of river water (see Soulsby et al. this volume) - in 
dry summers groundwater is the main component of water in rivers and therefore helps to sustain the public water supply network.

\section{Industrial use of groundwater}

Groundwater has many important industrial uses. Most notably for bottled water where the perception of green glens and pristine low salinity groundwaters has been used to good effect despite the vulnerability of some of these sources to anthropogenic pollution (Robins \& Ferry, 1992). Scottish mineral water companies supply $40 \%$ of the UK bottled water requirements, a market that has a total value of $£ 1$ billion. Both the total market, and Scotland's have been growing significantly over the past 10 years. The whisky industry (currently worth over $£ 2$ billion) to the Scottish economy also uses groundwater, and plays heavily on the mystery of the groundwater sources (Cribb 1998). However, the largest industrial users are for more mundane purposes: vegetable washing and processing, fish farming, golf courses and cooling in manufacturing.

\section{Agriculture}

Agriculture is an important user of groundwater in Scotland. There are approximately 200 irrigation boreholes, mainly located in eastern Scotland around Strathmore, the Borders and Aberdeenshire. These boreholes only abstract in the summer months, from June to August/September, and will not operate in wet years. Recent dry summers have seen a marked increase in the number of irrigation boreholes being drilled. More widely dispersed are small farm supplies, for cattle watering and washing in dairy, poultry or pig farms. There are probably in excess of 500 boreholes drilled for farm use, and many more make use of springs and wells. 


\section{Private water supplies}

There are thought to be between 20000 and 30000 private water supplies in Scotland, mostly abstracting groundwater from springs, wells and boreholes. Accurate statistics for both the number of private water supplies and the volume of groundwater used are difficult to find. According to official statistics from the drinking water regulator in Scotland (DWQR 2003) there are approximately 18000 private supplies for domestic use, and 2000 for commercial use (e.g. hotels and campsites). They estimate that 80 000 people are dependent on private water supplies for domestic use and 60000 through commercial use. In total this amounts to approximately $40 \mathrm{Ml} / \mathrm{d}$. Other estimates from work carried out by the Macaulay Institute for SEPA have both the number of sources and the amount abstracted considerably higher (Reid et al. 1999): 30 000 sources and abstraction $>100 \mathrm{Ml} / \mathrm{d}$.

The quality of water from private water supplies is a serious issue. Reid et al. (2003) found a high proportion of supplies in Aberdeenshire contaminated with coliforms and elevated nitrate concentrations.

\section{Environmental use}

The environmental use of groundwater is rarely documented or accounted for. Groundwater sustains river flows throughout the year and even in small upland streams may account for $30 \%$ of the flow, invaluable for sustaining Salmon populations (Soulsby et al. 2000) and keeping streams and rivers viable over dry summers. In addition, groundwater has an important role in sustaining wetlands and fragile 
ecologies, such as parts of the machair. Another use, rarely accounted for, is the ability of groundwater to assimilate, dilute and breakdown contaminants and waste.

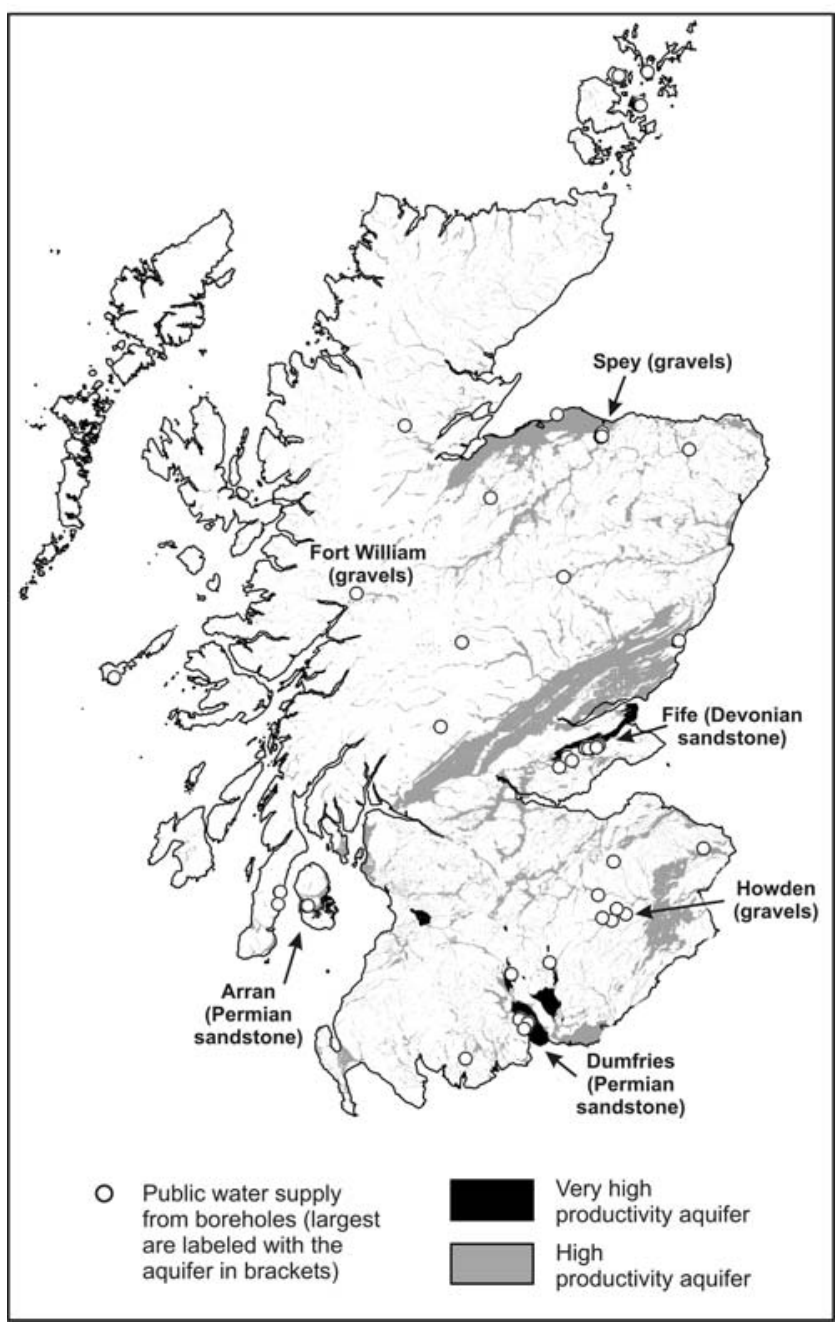

Figure 4 Public water supply boreholes in Scotland

\section{Threats to groundwater}

Groundwater in Scotland is under threat from anthropogenic activity. The most pressing problems are contamination from agricultural activity and the legacy of mining in Scotland; over-abstraction of groundwater is not yet a serious problem. Figure 5 
shows the location of some of the major threats to groundwater quality: mining and agricultural nitrate.

Nitrate concentrations in Scotland are elevated and, across approximately $14 \%$ of Scotland, at risk of exceeding the EU standard of $50 \mathrm{mg} / \mathrm{l}$. Ball et al. (2004) describes in detail the nitrate problem in Scotland and the process for identifying nitrate vulnerable zones (NVZs). Within these zones, new guidelines for the use of fertilizer and the spreading of slurry have been issues and should help to reverse the trend of rising nitrate. Other agricultural contaminants, such as phosphate, pesticides and herbicides are also elevated in several locations.

Scotland's long history of mining has left a legacy that threatens groundwater quality. Figure 5 shows the location of much of Scotland's shallow mining $(<200 \mathrm{~m})$ mainly for coal; the locations of metalliferous occurrences (many of which have been mined) are also shown. Contamination from the flooding of abandoned coal mines has already contaminated much of the groundwater in central Scotland and threatens surface water quality where the groundwater discharges at the surface (Younger 2001). The small metaliferous mines across Scotland could also lead to localised contamination of groundwater, although there has been no serious study of this issue and little understanding of the scope of the problem. 


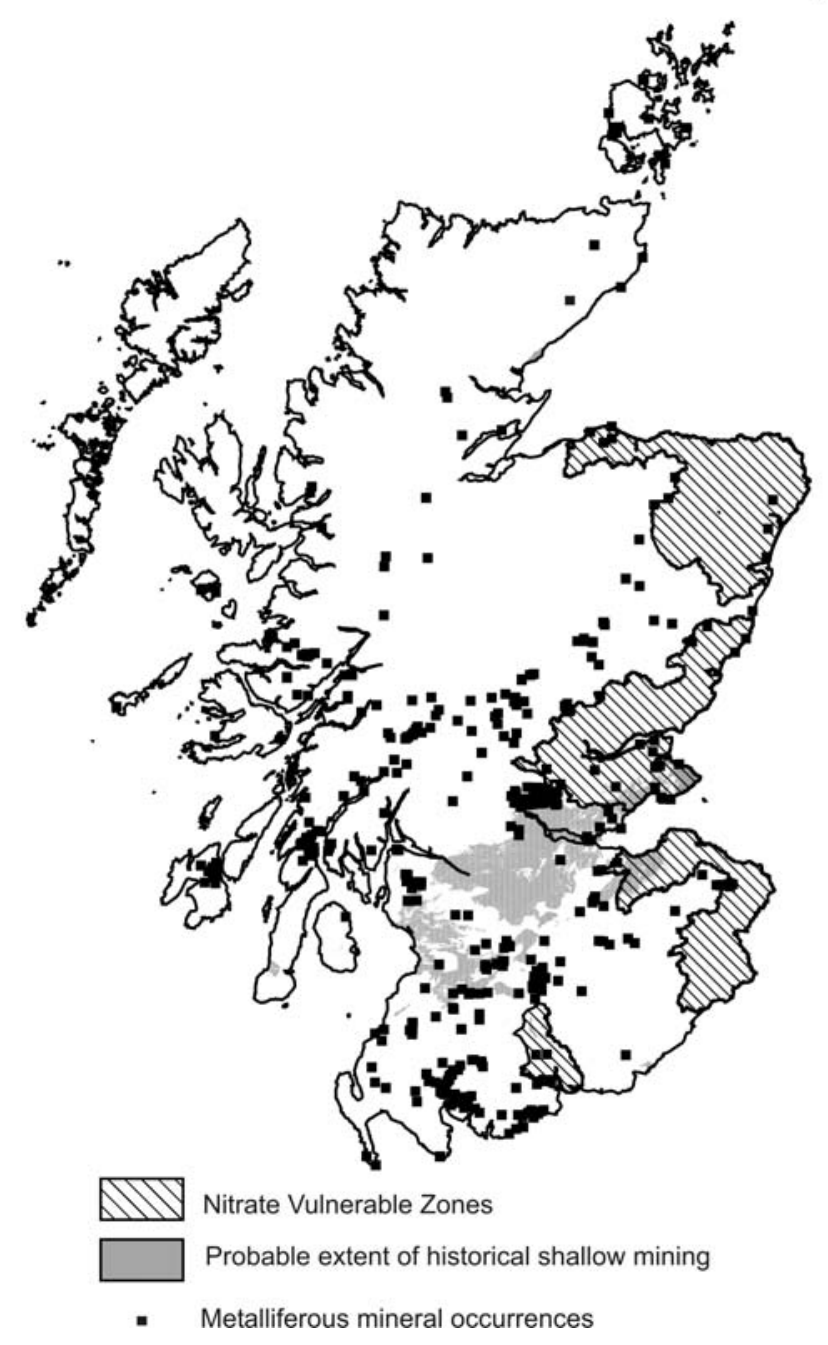

Figure 5 The location of two of the major threats to groundwater quality in Scotland: nitrate from agriculture and contamination from mining.

Ongoing development of Scotland's land surface also threatens groundwater quality. Contaminated land, building foundations, landfill sites, septic tanks, petrol stations, road drainage and the disposal of sheep dip and other wastes all need to be managed in such a way that groundwater is protected for future generations. One of the main ways of ensuring that groundwater is taken into account in land use planning is through the use of groundwater vulnerability maps. Ó Dochartaigh et al. (this volume) describes the development of a groundwater vulnerability screening tool for Scotland which will be 
used as part of the implementation of the EU Water Framework Directive in Scotland (Clews et al. this volume).

\section{Conclusions}

Scotland has a long history of using groundwater for private domestic supply. However, the development of hydrogeology as a science in Scotland only started in the 1970s and has recently been given a boost by the EU Water Framework Directive.

Groundwater is present throughout much of Scotland, both in bedrock and superficial deposits. The most productive bedrock aquifers are the Permian sandstones and breccia in southwest Scotland and the Devonian sandstones in Fife, Strathmore and Morayshire. Alluvium and fluvio-glacial sands and gravels also form important aquifers and provide some of Scotland's most high yielding boreholes.

There has been little systematic survey of the natural groundwater quality in Scotland; but what data exist indicate that groundwater is generally weakly mineralised with total dissolved solids in the range 100 to $500 \mathrm{mg} \mathrm{l}^{-1}$ and is dominated by $\mathrm{Ca}$ and $\mathrm{HCO}_{3}$. There are obvious exceptions, most noticeably in the Spa towns. There are elevated concentrations of nitrate where agricultural activity is intense and high iron and manganese in some superficial deposits.

There are in excess of 4000 boreholes in Scotland and over 20000 springs and wells used for private water supply. There is little available data on the volumes of groundwater abstracted. However, estimates suggest that the total volume may be approximately 330 megalitres per day. The volume of groundwater used in public 
water supply is growing annually; currently $7 \%$ of the daily 2400 megalitres per day supplied by Scottish Water is from groundwater sources.

Scottish groundwater needs to be managed and is under threat from agricultural activity, the mining legacy, septic tanks and general land development. The EU Water Framework Directive provides a useful framework to continue to use, manage and protect groundwater over the coming years.

\section{Acknowledgements}

Aspects of the work described in this paper have been funded by SEPA and Scottish Water. We thank Allan Lilly of the Macaulay Institute and Vincent Fitzsimons of SEPA for helpful discussions on certain aspects of the work described in the paper. This paper is published by permission of the Executive Director of the British Geological Survey (NERC).

\section{References}

ADRIS 1995. Groundwater Protection Strategy for Scotland. Association of Directors and River Inspectors of Scotland, Perth.

Ball, D. F. \& Buckley, D. K. 1998. Hydrogeological investigations in the Machrie area of Arran. British Geological Survey Technical Report, WD/98/49R.

Ball, D. F., MacDonald, A. M. \& Lilly, A. 2004. Nitrate vulnerable zones in Scotland. This volume. 
Ball, D. F., MacDonald, A. M., Ó Dochartaigh, B. É., del Rio, M., Fitzsimons, V., Auton, C. A. \& Lilly, A. 2003. Development of a groundwater vulnerability screening methodology for the Water Framework Directive. British Geological Survey Technical Report CR/03/249N.

Boorman, D. B., Hollis, J. M. \& Lilly, A. 1995. Hydrology of soil types: a hydrologically-based classification of the soils of the United Kingdom. Institute of Hydrology Report, 126, Institute of Hydrology, Wallingford.

British Geological Survey 1988. Hydrogeological Map of Scotland, 1: 625 000, British Geological Survey, Edinburgh.

Buckley, D. K. 2000. Some case histories of geophysical downhole logging to examine borehole site and regional groundwater movement in Celtic regions. In: Robins, N. S. \& Misstear, B. D. R. (eds) Groundwater in the Celtic regions: studies in hard-rock and Quaternary hydrogeology. Geological Society, London, Special Publications, 182, 219238.

Cheney, C. S. \& MacDonald, A. M. 1993. The hydrogeology of the Dumfries basin. British Geological Survey Technical Report WD/93/46C

Clews, J, Fitzsimons, V. \& Simpson, E. 2004. Groundwater challenges of the Water Framework Directive in Scotland. This volume

Cook, J. M., Edmunds, W. M. \& Robins, N. S. 1991. Groundwater contributions to an acid upland lake (Loch Fleet, Scotland) and the possibilities for amelioration. Journal of Hydrology, 125, 111-128. 
Cribb, S. J. 1998. Whisky on the Rocks - origins of the water of life. British Geological Survey, Keyworth.

Cumming, G. A. 1936. Underground water circulation. Geological factors and complications affecting it in the Midland Valley of Scotland. Water and Water Engineering (June 1936), 319-322.

DWQR 2003. Drinking water quality in Scotland 2002. Drinking Water Quality Regulator, Edinburgh.

Grose, A. B. F. Smith, A. J., Donn, A. O’Donnell, J. \& Welch, D. 1998. Supplying high quality drinking water to remote communities in Scotland. Desalination, 117, 107117.

Johnstone, J. M. \& Rennie, G. M. 1991. Development of a new water supply for Fort William. Journal of the Institution of Water \& Environmental Management, 5, 503512.

Jones, C. R. C. \& Singleton, A. J. 2000. Public water supplies from alluvial and glacial deposits in northern Scotland. In: Robins, N. S. \& Misstear, B. D. R. (eds) Groundwater in the Celtic Regions: studies in hard rock and Quaternary Hydrogeology, Geological Society, London, Special Publications, 182, 133-140.

Kay, R. L. F. 1984. Generation of groundwater salinity by low-temperature granitewater interaction: a comparison of results from two British studies. International Symposium on Groundwater Resources Utilisation and Contaminant Hydrogeology, Montreal, 432-444. 
Lilly, A., Boorman, D. B., \& Hollis, J. M. 1998. The development of a hydrological classification of UK soils and the inherent scale changes. Nutrient Cycling in Agroecosystems, 50, 299 - 302.

MacDonald, A. M., Ball, D. F. \& McCann, D. M. 2000. Groundwater exploration in rural Scotland using geophysical techniques. In: Robins, N. S. \& Misstear, B. D. R. (eds) Groundwater in the Celtic Regions: studies in hard rock and Quaternary Hydrogeology, Geological Society, London, Special Publications, 182, 205-217.

MacDonald, A. M., Ball, D. F. \& Ó Dochartaigh, B. É., 2004. A GIS of aquifer productivity in Scotland: explanatory notes. British Geological Survey Technical Report CR/04/047N.

MacDonald, A. M., Darling, W. G., Ball, D. F. \& Oster, H. 2003. Identifying trends in groundwater quality using residence time indicators: an example from the Permian aquifer of Dumfries, Scotland. Hydrogeology Journal, 11, 504-517.

Ó Dochartaigh, B. É., Ball, D. F., Browne, M. A. E., Shand, P., MacDonald, A. M., Robins, N. S. \& McNeill, G. W., 1999. The Upper Devonian Sandstone aquifer of Fife. British Geological Survey Technical Report WD/99/39.

Ó Dochartaigh, B. É., Ball, D. F., MacDonald, A. M., Lilly, A., Fitzsimons, V., del Rio, M. \& Auton, C. A. 2004. Mapping groundwater vulnerability in Scotland: a new approach for the Water Framework Directive. This volume. 
Reid, D. C., Edwards, A. C., Cooper D., Wilson, E. \& McGraw, B. A. 2003. The quality of drinking water from private water supplies in Aberdeenshire, UK. Water Research, 37, 245-254.

Reid, D. C., Lilly, A., McGaw, B. Malcolm, A., Montgomery, L. \& McKeen, M. M. 1999. Report summarising Local Authority Data on Private Water Supplies in Scotland. Report prepared for SEPA and the Scottish Executive. Contract No: 230/4006.

Robins, N. S. 1990. Hydrogeology of Scotland. HMSO, London.

Robins, N. S. 2002. Groundwater quality in Scotland: major ion chemistry of the key groundwater bodies. The Science of the Total Environment, 294, 41-56.

Robins, N. S. \& Ball, D. F. (eds) in press. The Dumfries aquifer basin. Hydrogeological Report Series of the British Geological Survey.

Robins, N. S. \& Buckley, D. K. 1988. Characteristics of the Permian and Triassic aquifers of south-west Scotland. Quarterly Journal of Engineering Geology 21, 329325.

Robins, N. S., Bennett, J. R. P. \& Kullen, K. T. 2004. Groundwater versus surface water in Scotland and Ireland - the formative years. In: J D Mather (Ed.), 200 years of British hydrogeology. Geological Society, London, Special Publications, 225.

Robins, N. S. \& Ferry, J. M. 1992. Natural mineral waters: a Scottish perspective. Quarterly Journal of Engineering Geology, 25, 1, 65-71. 
Soulsby, C., Chen, M., Ferrier, R. C., Jenkins, A. \& Harriman, R. 1998. Hydrogeochemistry of shallow groundwater in an upland Scottish catchment. Hydrological Processes, 12, 1111-1127.

Soulsby, C., Malcolm, R. \& Malcolm, I. 2000. Groundwater in headwaters: hydrological and ecological significance. In: Robins, N. S. \& Misstear, B. D. R. (eds) Groundwater in the Celtic Regions: studies in hard rock and Quaternary Hydrogeology, Geological Society, London, Special Publications, 182, 19-34.

Soulsby, C., Malcolm, I. A., Youngson, A. F., Tetzlaff, D., Gibbins, C. N. \& Hannah, D. M. 2004. Groundwater-surface water interactions in upland Scottish rivers: hydrological, hydrochemical and ecological implications. This volume.

Watt, G. D., Mellanby, J. F. van Wonderen, J. J. \& Burley, M. 1987. Groundwater investigations in the lower Spey valley, near Fochabers. Journal of the Institution of Water \& Environmental Management, 1, 89-103.

Wood, S. C., Younger, P. L. \& Robins N. S. 1999. Long term changes in the quality of polluted minewater discharges from abandoned underground coal workings in Scotland. Quarterly Journal of Engineering Geology, 32, 69-79.

Younger, P. L. 2001. Mine water pollution in Scotland: nature, extent and preventative strategies. The Science of the Total Environment, 265, 309-326. 